\title{
Leuctra quadrimaculata Kis, 1963 (Plecoptera; Leuctridae) in the Moravskoslezské Beskydy Mts. and Javorníky Mts. (Czech Republic)
}

Jiří Kroča

Leuctra quadrimaculata Kis, 1963 (Plecoptera; Leuctridae) in the Moravskoslezské Beskydy Mts. and Javorníky Mts. (Czech Republic).- Čas. Slez. Muz. Opava (A), 60: 57-62, 2011.

\begin{abstract}
The paper brings new information on the distribution of Leuctra quadrimaculata Kis, 1963 in the Czech Republic. Until now, it was known only from the one locality in the Bílé Karpaty Mts. (Bojková \& Špaček, 2006). The imagines of L. quadrimaculata were collected at five localities in the Outer Western Carpathians (3 localities in the Moravskoslezské Beskydy Mts., subunit Klokočovská hornatina and 2 localities in Javorníky Mts.). Presented records confirm the occurrence of the species in the Czech Republic and they are the first records in the Moravskoslezské Beskydy Mts. and Javorníky Mts.

Key words: Leuctra quadrimaculata, Plecoptera, Moravskoslezské Beskydy Mts., Klokočovská hornatina, Javorníky Mts., Moravia, Czech Republic
\end{abstract}

\section{Introduction}

Detailed hydrobiological investigation of running waters in the Moravskoslezské Beskydy Mts. and Javorníky Mts. was conducted in 2006-2009 (Kroča et al., 2007). The important part of this investigation was extensive sampling of imagines of aquatic insects to describe species diversity of studied area and to validate identifications of species in the larval stage. During this investigation several rare and endangered species have been found (Kroča, 2010a; 2010b, 2010c). In this paper, new records of the stonefly Leuctra quadrimaculata in the Moravskoslezské Beskydy Mts. and Javorníky Mts. are presented.

L. quadrimaculata is Carpathian and Balkanian species. It occurs in Bulgaria (Braasch \& Joost, 1971); Serbia (Kaćanski,1975); Montenegro (Kaćanski \& Baumann 1981); Macedonia (Ikonomov, 1976, 1979, 1983, 1986) Bosnia and Hercegovina (D. Murányi, per. comm.), and Albania (D. Murányi, per. comm.). It was recorded in the whole Carpathians - Romania (Kis, 1963; Murányi, 2006), Ukraine (Murányi, 2006) Slovakia (Krno, 2002, 2007) and Poland (Sowa, 1970; Kittel \& Wojtas, 2002). In the Czech Republic, the species is known from the only locality the Hrušovka stream near Kaňoury (the Bílé Karpaty Mts.) (Bojková \& Špaček, 2006) (Fig. 2.).

Despite a wide geographical distribution (from mountain systems of southeast Europe to Western Carpathians in Central Europe), L. quadrimaculata is relatively rare species (D. Murányi, pers. com.).

\section{Material and Methods}

Entomological part of the investigation of main running water habitats of the Moravskoslezské Beskydy Mts. and the Javorníky Mts. was conducted in 2007-2009.

Imagines were collected by Malaise traps which were exposed during the whole vegetation season and sampled every three to five weeks. In 2007 Malaise traps were placed at 8 localities in Moravskoslezské Beskydy Mts. and at 2 localities in the Javorníky Mts. (in the Kychová River basin). In 2008-2009 they were installed at 16 localities, 14 localities in the Moravskoslezské Beskydy Mts. and 2 localities in the Podbeskydská Pahorkatina Upland - Morávka River basin. Imagines were also collected by sweeping at 11 localities along the longitudinal profile of the Morávka River (10) and in the Slavíč brook (1) in 2003-2009. In total, samples collected at 37 localities were examined in this study.

Material was conserved by Ethanol (70\%) and it is deposited in the T. G. M. Water Research Institute, p. r. i. Prague, branch Brno (coll. J. Kroča). 
Tab 1: Localities of L. quadrimaculata occurrence

\begin{tabular}{|c|c|c|c|c|c|}
\hline \multirow{2}{*}{ Locality } & \multirow{2}{*}{ Geomorphological unit } & \multirow{2}{*}{ Symbol } & \multicolumn{2}{|c|}{ Coordinate } & \multirow{2}{*}{$\begin{array}{l}\text { Altitude } \\
{[\mathrm{m} \text { a. s. } 1 .]}\end{array}$} \\
\hline & & & $\mathrm{N}$ & $\mathrm{E}$ & \\
\hline Salajka & MSB & SA & $49^{\circ} 24^{\prime} 7,215^{\prime \prime}$ & $18^{\circ} 25^{\prime} 16,685^{\prime \prime}$ & 719 \\
\hline Smradlava 1. & MSB & SM 1. & $49^{\circ} 24^{\prime} 37,454^{\prime \prime}$ & $18^{\circ} 26^{\prime} 36,18^{\prime \prime}$ & 634 \\
\hline Smradlava 2. & MSB & SM 2. & $49^{\circ} 25^{\prime} 15,244^{\prime \prime}$ & $18^{\circ} 26^{\prime} 57,149^{\prime \prime}$ & 600 \\
\hline Makyta & JAV & MA & $49^{\circ} 16^{\prime} 33,266^{\prime \prime}$ & $18^{\circ} 10^{\prime} 44,574^{\prime \prime}$ & 665 \\
\hline Malá Tisová & JAV & MT & $49^{\circ} 16^{\prime} 29,188^{\prime \prime}$ & $18^{\circ} 8^{\prime} 38,537^{\prime \prime}$ & 547 \\
\hline
\end{tabular}

Note: MSB - Moravskoslezské Beskydy Mts.; JAV - Javorníky Mts.

\section{Results and discussion}

\section{Leuctra quadrimaculata Kis, 1963.}

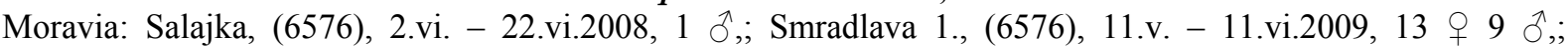
Smradlava 2., (6576), 11.v. - 11.vi.2009, 1 q,; Makyta, (6775), 14.v. - 11.vi.2007, 3 q ;; Malá Tisová, (6774), 14.v. - 11.vi.2007, 2 q 1 §,; Malá Tisová, (6774), 9.vii. - 6.viii.2007, 3 q 1 đ;; all J. Kroča leg., J. Kroča det. et coll.

New records of Leuctra quadrimaculata confirmed its occurrence in the Czech Republic (Bojková \& Špaček, 2006) and they represent the first records of the species in the Moravskoslezské Beskydy Mts. and in the Javorníky Mts.

It is likely that L. quadrimaculata can also occur in other small streams of the subunit Klokočovská hornatina (Moravskoslezské Beskydy Mts.), similarly to another stonefly species Leuctra bronislawi which was found recently (Kroča, 2010c). In the Javorniky Mts. L. quadrimaculata was recorded at both sites which were studied (Fig. 1.). Based on such a small number of studied localities, it is not possible to predict the distribution of the species in this geomorphologic unit.

Taking into account all known localities of L. quadrimaculata in the Carpathians in the Czech Republic, it is possible to conclude that its occurrence is linked to the upper sections of streams (hypokrenal - epirhitral) in less rugged mountains which are built by less resistant rocks, with a higher proportion of rocks with calcareous component (Magura nappe).

These localities markedly differ by their morphology and chemical conditions from the localities in the northern part of the Moravskoslezské Beskydy Mts. which are built by largely resistant sandstone without high content of calcareous rocks (Silesian nappe).

Based on these findings, it can be assumed that L. quadrimaculata may also occur in other mountains of the Outer Western Carpathians, which consist of rocks of the Magura nappe and have a similar morphology as the Klokočovská hornatina (subunit of the Moravskoslezské Beskydy Mts.) or the Javorníky Mts. (e.g. Vsetínské vrchy or Jablunkovské Mezihoří).

Variability of tergal ornamentations in the populations of the Moravskoslezské Beskydy Mts. and the Javorníky Mts. is large (Fig. 5.). No specimen examined had the tergal ornamentations described the Romanian population (Kis, 1974; Fig. 3.). Determination of male was based on the shape of the paraproct (stylus and specillus) (Fig. 4.), which is the main determination character in the genus Leuctra. 
and helpful comments on the manuscript and Mgr. Igor Konvit for processing of the map of L. quadrimaculata distribution.

\section{References:}

Bojková J. \& Špaček J. (2006): New and interestin records of Plecoptera (Insecta) from the Czech Republic.- Acta Musei Moraviae, Scientiae biologicae, Brno, 91: 1- 6 .

Demek J. \& Mackovčin P. eds. (2006): Hory a nížiny. Zeměpisný lexikon ČR. Agentura ochrany přírody a krajiny ČR, Brno, $582 \mathrm{~s}$.

Braasch D. \& Joost W. (1971): Zur Plecopterenfauna Bulgariens.- Limnologica 8: 265.295.

Fialkowski W. \& Kittel W. (2002): Katalog fauny Polski, Widelnice (Plecoptera). Muzeum i Institut Zoologii PAN, 75s.

Ikonomov P. (1976): Rasprostranetost na Plecoptera (Insecta) vo tečeškite vodi na SR Makedonija vo odnos na temperaturniot faktor. VIII. Vevčanski potok (Jablanica planina).- Prirodonaučen muzej na Makedonija, Skopje, posebno izdanije no. 7: 57-69.

Ikonomov P. (1979): Plecoptera (Insecta) od slivot na Rekata Radika.- Annuaire de la Faculté de Biologie de l'Université „Kiril et Metodij“" de Skopje, 32: 45-60.

I k o n o mov P. (1983): Nouveles espèces de Plécoptères (Insecta, Plecoptera) de Macédoine III.Fragmenta Balcanica Musei Macedonici Scientiarum Naturalium, Skopje, 9: 175-183.

Ikonomov P. (1986): Nov prilog kon poznavanieto na plekopterite (Insecta, Plecoptera) na Makedonija.Fragmenta Balcanica Musei Macedonici Scientiarum Naturalium, 13: 1-9.

Kaćanski D. (1975): Plecoptera u području planine Zlatibor.- Zbornik radova o entomofauni SR Srbije, knjiga I, Srbske akademije nauka i umetnosti, 237-245.

Kaćanski D. \& Baumann R. W. (1981): Notes on the Plecoptera Fauna of the Morača River Drainage. In: Karaman, G. S. \& Beeton, A. M. (eds) The Biota and Limnology of Lake Skadar, Univerzitet Veljko Vlahović - Smithsonian Institution - University of Wisconsin, Titograd, pp. 304-307.

Kis B., (1974): Plecoptera, Insecta. Fauna Rep. Soc. Romania. Vol. 8 Acad. Rep. Soc. Romania, Bucuresti, $273 \mathrm{pp}$.

Krno I. (2002): Pošvatky (Plecoptera) pramenísk a horských a podhorských tokov povodia Bodrogu.- Acta Fac. Ecol. 9: $67-78$.

- (2007): Plecoptera. In: Novikmec, M., Svitok, M. \& Bitušík, P. (eds.) Limnology of streams in the Poloniny National Park (the East Carpathians, Slovakia). - 1. vyd. - Zvolen : Technical University, 2007, 69 s.

Kroča J. (2010a): Leuctra digitata Kempny, 1899 (Plecoptera: Leuctridae) in the Moravskoslezské Beskydy Mts. and Podbeskydská pahorkatina Upland region of the Czech Republic.- Čas. Slez. Muz. Opava (A), 59: 71-75.

- (2010b): Arcynopteryx compacta (Mac Lachlan, 1872) and Isogenus nubecula Newman, 1833 (Plecoptera, Perlodidae) in the Moravskoslezske Beskydy Mts. (Czech Republic).- Čas. Slez. Muz. Opava (A), 59: 146151.

- (2010c): The first record of Leuctra bronislawi (Plecoptera, Leuctridae) in the Czech Republic.- Čas. Slez. Muz. Opava (A), 59: 146-151.

Kroča J., Skácelová O., Kuras T. \& Uher B. (2007): Influence of forest ecosystems on the outflow water quality, fauna and flora - methodical selection of sites, evaluation factors and preliminary results of macrozoobenthos, fytobentos and chemical analyses. Second International Conference on Waters in Protected Areas, Conference proceedings, 24. - 28. April 2007, Dubrovnik, 297 - 301.

Murányi D. (2006): Comparison of Leuctra kisi Steinmann, 1968 with Leuctra quadrimaculata Kis, 1963 (Plecoptera, Leuctridae), and the first record of L. quadrimaculata from Ukraine.- Opusc. Zool. Budapest, 35: 73-75.

Sivec I. (1980): Catalogus faune Jugoslavie, 3/6 Plecoptera. Acad. Sc. Art. Slovenica, Ljubljana, Slovenia, 30 pp.

Sowa R. (1970): Note sur quelques Plecoptéres de la Pologne. Bull. Acad. Polon. Sci. 18: 153-157.

Author's address: Jiří Kroča, T.G.Masaryk Water Research Institute Public Research Institution, Mojmírovo nám. 16, 612 00, Brno, Czech Republic, e-mail: jiri_kroca@vuv.cz 


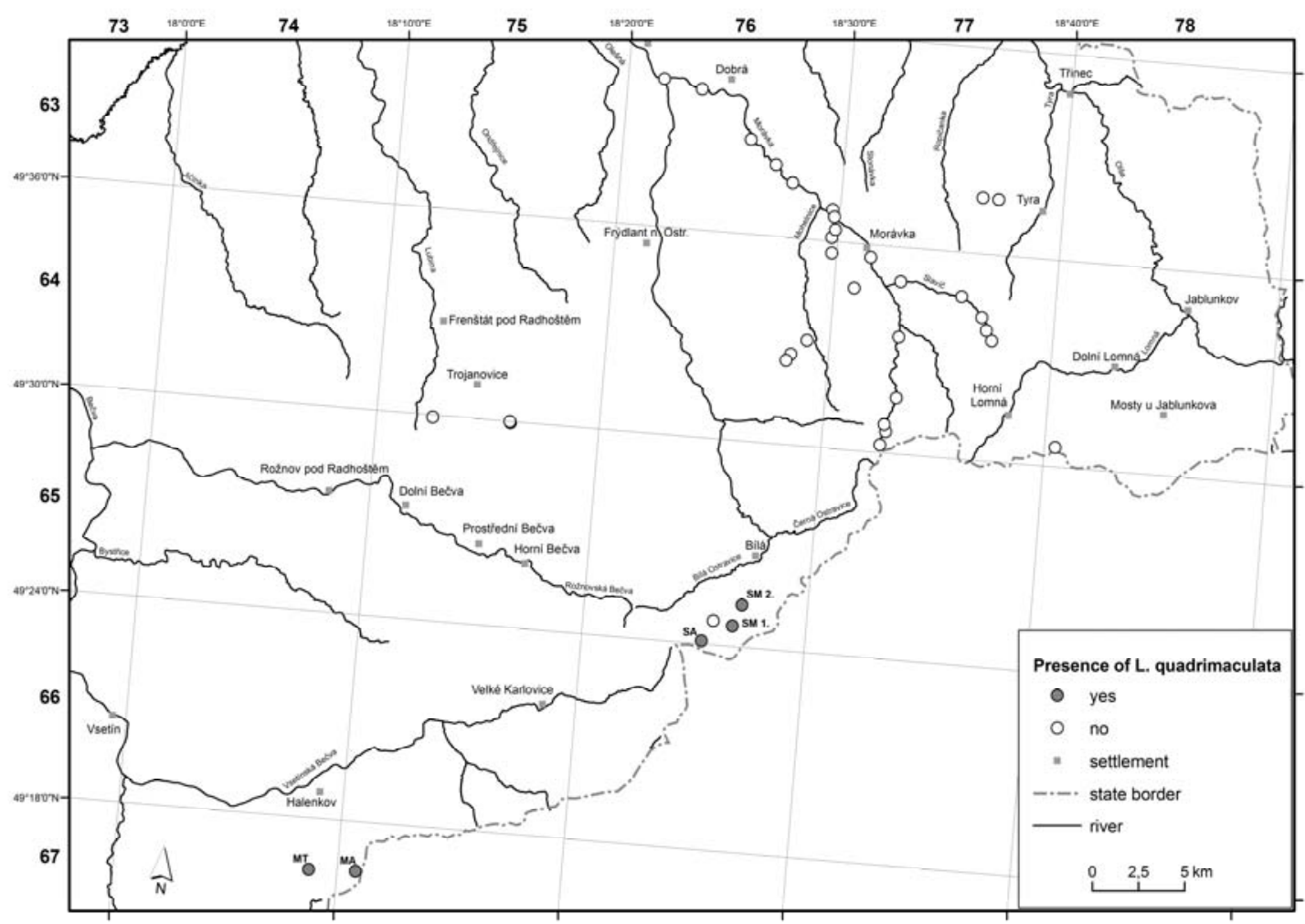

Fig 1: The presence and absence of Leuctra quadrimaculata in studied localities of the Moravskoslezské Beskydy Mts. and Javorníky Mts.

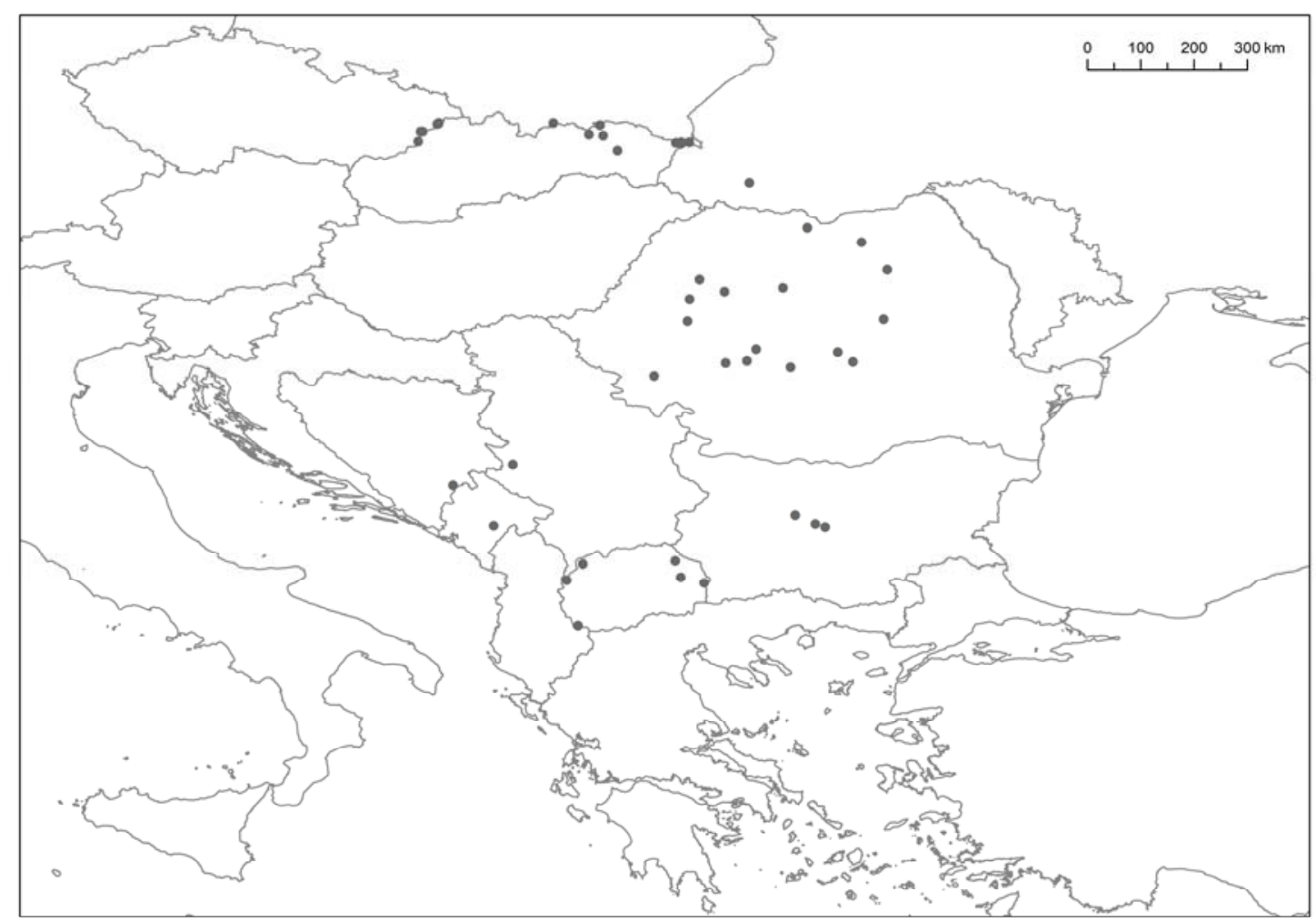

Fig 2: Known occurrence of Leuctra quadrimaculata in the Southeastern and Central Europe 


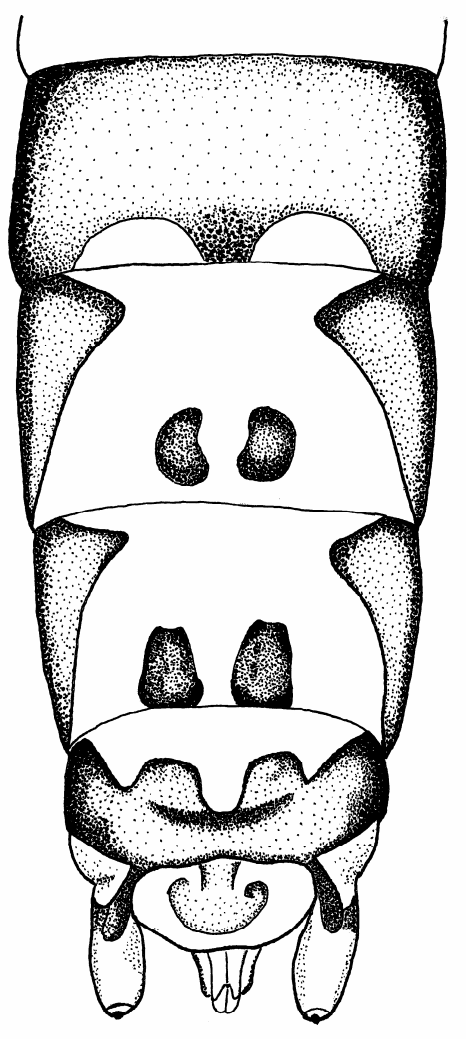

Fig 3: Leuctra quadrimaculata: male abdomen, dorsal view (J. Kroča according to Kis, 1974)

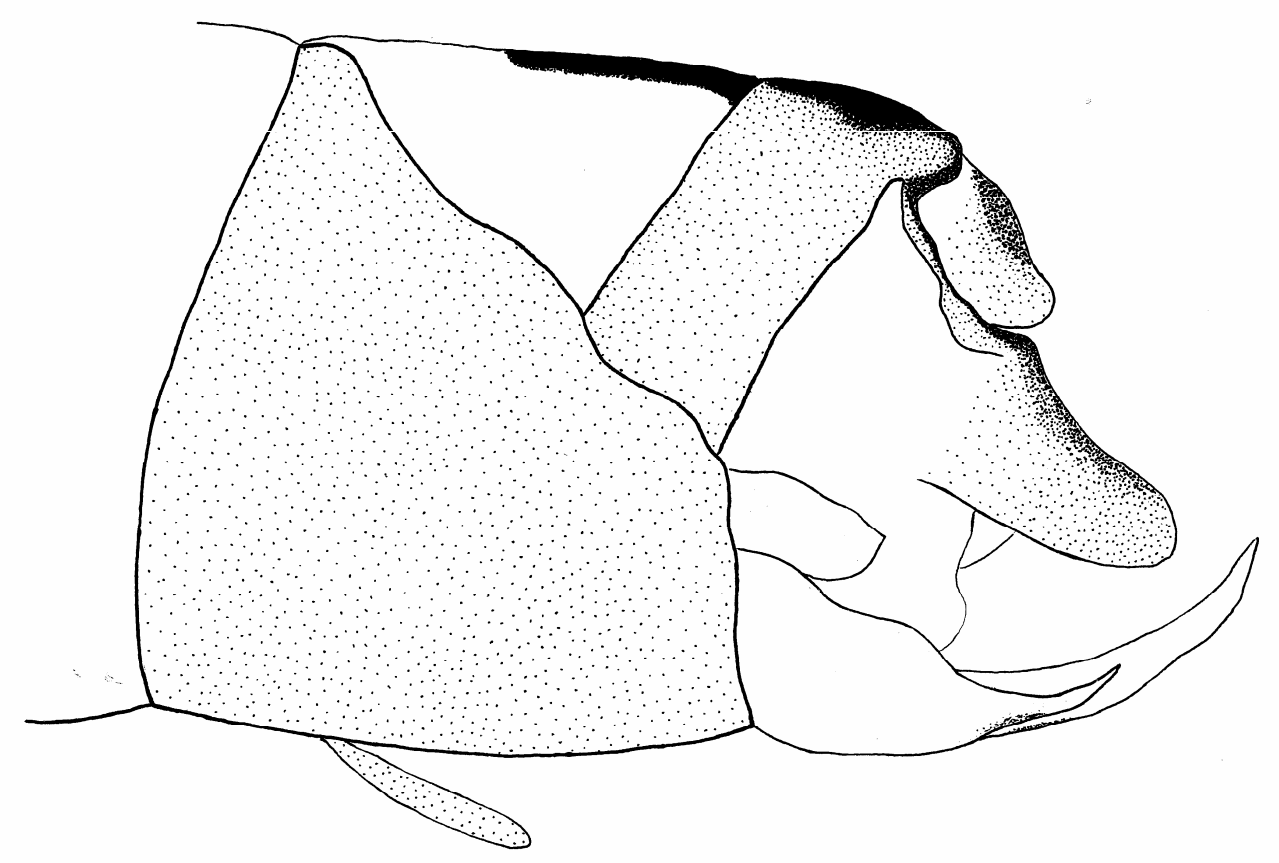

Fig 4: Leuctra quadrimaculata: male paraproct, lateral view (J. Kroča) 

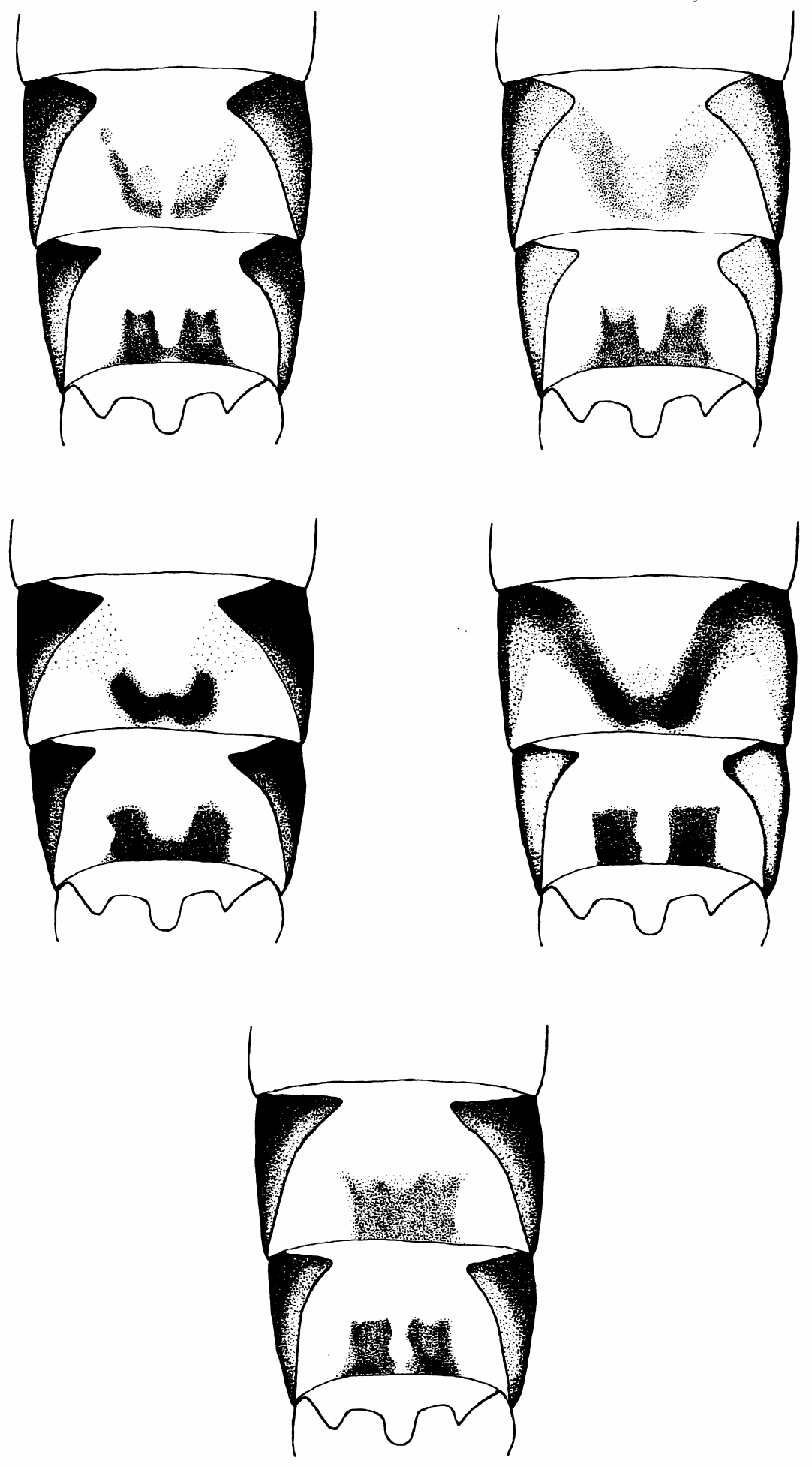

Fig 5: Leuctra quadrimaculata: variability of tergal ornamentations on 8th and 9th segments of abdomen, dorsal view (J. Kroča) 